\title{
Inhibition of the Expression of Cell-associated Fructosyltransferase in Streptococcus salivarius by Octyl $\beta$-D-Glucopyranoside
}

\author{
By NICHOLAS A. JACQUES \\ Institute of Dental Research, United Dental Hospital of Sydney, Chalmers Street, Surry Hills, \\ NSW 2010, Australia
}

(Received 29 March 1985; revised 12 July 1985)

Octyl $\beta$-D-glucopyranoside prevented the expression of cell-associated fructosyltransferase activity in Streptococcus salivarius ATCC 25975 grown in batch culture or incubated in nonproliferating cell suspension medium. This effect was not due to the direct inhibition of enzyme activity nor due to the loss of active enzyme into the external medium. The prevention of enzyme expression did not appear to be due to the inhibition of a general translocation mechanism for protein secretion, since fructosyltransferase activity was not detected within the cytoplasm of lysed cells grown in the presence of octyl $\beta$-D-glucopyranoside; nor was there any observed inhibition of the secretion of the extracellular enzyme glucosyltransferase. These and other observations supported the view that fructosyltransferase was not secreted across the cytoplasmic membrane in an active form before becoming associated with the cell surface.

\section{INTRODUCTION}

The fructosyltransferase activity of Streptococcus salivarius is essentially cell-associated, with up to $95 \%$ of the activity bound to the cell (Garszczynski \& Edwards, 1973; Jacques \& Wittenberger, 1981). However, it is not known whether the enzyme is an integral part of the outer surface of the cell membrane or is attached to the peptidoglycan-polysaccharide matrix of the cell wall sacculus. In the former case it could be argued that fructosyltransferase was indeed a membrane protein with its active site on the outer surface of the cytoplasmic membrane similar to the bacterial leader peptidase of Escherichia coli (Wolfe \& Wickner, 1984). In the latter case the enzyme could be considered to be a secreted protein similar to the outer membrane proteins of Gram-negative bacteria (Ichihara et al., 1982), but presumably possessing a location similar to the major cell wall protein antigens of oral streptococci (Russell et al., 1983 b).

In contrast to the cell-associated nature of fructosyltransferase, more than $99 \%$ of glucosyltransferase activity in $S$. salivarius is expressed in the external medium. By definition, therefore, glucosyltransferase is an extracellular enzyme. Studies on the mechanisms of expression of glucosyltransferase have shown that the fatty acid dodecanoic acid prevents the synthesis and secretion of this enzyme, while the non-ionic detergent Tween 80 (polyoxyethylene sorbitan mono-oleate) stimulates its production (Wittenberger et al., 1978; Jacques, 1983). These effects are believed to be due in part to an alteration in the fluidity of the membrane (Jacques et al., 1985). The fatty acid is presumed to intercalate with the membrane (PetitGlatron \& Chambert, 1981), while the detergent is known to enhance the number of octadecenoic acid residues present in the membrane lipids (Umesaki et al., 1977; Jacques et al., 1985). It is reasonable to suggest, therefore, that if fructosyltransferase were essentially a secreted protein associated with the cell-wall sacculus, then its expression on the cell surface would be modulated in a similar manner to glucosyltransferase by amphiphilic compounds. For this reason, the formation of cell-associated fructosyltransferase has been investigated in the presence of dodecanoic acid and Tween 80, and these studies have been further extended by using the non-ionic detergent octylglucoside (octyl $\beta$-D-glucopyranoside) which is known to disrupt membrane structure (Helenius et al., 1979; Alonso et al., 1982). 
While differences in the degree of modulation of the expression of cell-associated fructosyltransferase and extracellular glucosyltransferase were apparent when cells were incubated in the presence of either dodecanoic acid or Tween 80 , the differential effects of octylglucoside on the expression of these two enzymes supported the hypothesis that their mechanisms of expression differed, and that this difference was most probably associated with the final location of the two proteins relative to the cell surface.

\section{METHODS}

Chemicals. [U-glucosyl $\left.{ }^{1+} \mathrm{C}\right]$ sucrose, [U-fructosyl $\left.{ }^{1+} \mathrm{C}\right]$ sucrose and the liquid scintillation cocktail Aquasol-2 were purchased from New England Nuclear. Octylglucoside (octyl $\beta$-D-glucopyranoside) and chloramphenicol were purchased from Calbiochem-Behring, dodecanoic (lauric) acid from Ajax Chemicals, CM-Sephadex G25 from Pharmacia and Tween 80 (polyoxyethylene sorbitan mono-oleate) from BDH. The M-I enzyme preparation from Streptomyces globisporus 1829 was kindly supplied by K. Yokogawa, Dainippon Pharmaceutical Co. Ltd, Osaka, Japan.

Organisms and growth. Streptococcus salivarius ATCC 25975 was stored or grown in semi-defined medium as previously described (Jacques, 1983), except that all batch cultures contained $1 \mathrm{~mm}-\mathrm{CaCl}_{2}$. All experiments reported were repeated at least once and the data presented are typical of those obtained.

Non-proliferating cell suspensions. These were used to monitor the expression of cell-associated fructosyltransferase activity and extracellular glucosyltransferase activity. The suspension medium was essentially the same as that previously described except that $1 \mathrm{mM}-\mathrm{CaCl}_{2}$ was routinely added (Jacques, 1983). In order to prepare $S$. salivarius free of cell-associated fructosyltransferase activity, cells from a $100 \mathrm{ml}$ culture were harvested by centrifugation at mid-exponential phase $\left(10000 \mathrm{~g}, 4^{\circ} \mathrm{C}, 10 \mathrm{~min}\right)$, and treated for $30 \mathrm{~min}$ in the standard inactivation system described by Jacques \& Wittenberger (1981). Following this treatment, the cells were harvested by centrifugation $\left(10000 \mathrm{~g}, 4^{\circ} \mathrm{C}, 10 \mathrm{~min}\right)$, washed and resuspended to $6 \mathrm{ml}$ in $10 \mathrm{~mm}$-potassium phosphate buffer, pH 6.5, containing $10 \mathrm{~mm}-\mathrm{MgSO}_{+}$. These cells were used to prepare non-proliferating cell suspensions. The inclusion of $10 \mathrm{mM}-\mathrm{Mg}^{2+}$ in the washing buffer was essential for the subsequent production of both glycosyltransferase activities. Other ions tested fell into the sequence: none $<\mathrm{Mg}^{2+}(2 \mathrm{mM}) \ll \mathrm{Ba}^{2+}(2 \mathrm{mM})=\mathrm{Ca}^{2+}(2 \mathrm{mM})<\mathrm{Mg}^{2+}$

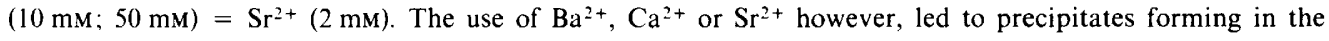
suspension medium.

Assay of glucosyltransferase activities. Extracellular glucosyltransferase activity and cell-associated fructosyltransferase activity were assayed as previously described, except that the assay mixture for measuring fructosyltransferase activity contained $1 \mathrm{~mm}-\mathrm{CaCl}_{2}$ (Jacques, 1983, 1984). One unit of enzyme activity (U) was defined as the amount of glucosyltransferase or fructosyltransferase that catalysed the incorporation of $1 \mu \mathrm{mol}$ of the glucose or of the fructose moiety of sucrose, respectively, into $75 \%(\mathrm{v} / \mathrm{v})$ ethanol-insoluble polysaccharide $\mathrm{min}^{-1}$. In the case of fructosyltransferase, the measured values were multiplied by a factor of $2 \cdot 2$ to account for the limiting concentration of sucrose in the assay system (Jacques, 1984).

Preparation and analysis of fatty acids. The membrane-bound lipids were extracted and the methyl esters of the fatty acids prepared and analysed as reported previously (Markevics \& Jacques, 1985).

Purification of the M-I enzyme preparation. The $N$-acetylmuramidase enzyme, M-1 (Yokogawa et al., 1975), was purified free from proteolytic activity on a CM-Sephadex G25 column $(90 \times 1.6 \mathrm{~cm})$ using $150 \mathrm{mM}$-sodium phosphate buffer, pH 7.0, as eluant (Siegel et al., 1981).

Lysis of cells. The initial rate of lysis of cells grown to early stationary phase was determined by monitoring the change in optical density at $37^{\circ} \mathrm{C}$ of cell suspensions $\left(0 \cdot 70-0.95 \mathrm{mg} \mathrm{dry} \mathrm{wt} \mathrm{ml}^{-1}\right)$ in $10 \mathrm{mM}$-potassium phosphate buffer, $\mathrm{pH} 6.5$, containing $10 \mathrm{~mm}-\mathrm{MgSO}_{4}, 1 \mathrm{mM}-\mathrm{CaCl}_{2}$ and $20 \mu \mathrm{g}$ purified $\mathrm{M}-1$ enzyme $\mathrm{ml}^{-1}$. Measurements were taken at $10 \mathrm{~min}$ intervals with a Corning colorimeter model 252 fitted with a $600 \mathrm{~nm}$ filter (Evans Electroselenium). Lysed cells were also used for measurements of intracellular fructosyltransferase activity.

\section{RESULTS}

Protein synthesis was shown to be required for the expression of cell-associated fructosyltransferase activity in non-proliferating cell suspensions after inactivation of the enzyme in the standard inactivation system (data not shown). However, the inactivation treatment not only gave variable results for the absolute amount of enzyme subsequently synthesized, but also substantially reduced the potential for the expression of both cellassociated fructosyltransferase and extracellular glucosyltransferase activities. The production of cell-associated fructosyltransferase was taken therefore as the difference between the level of activity on harvest and that after incubation for $120 \mathrm{~min}$ in the non-proliferating cell suspension 

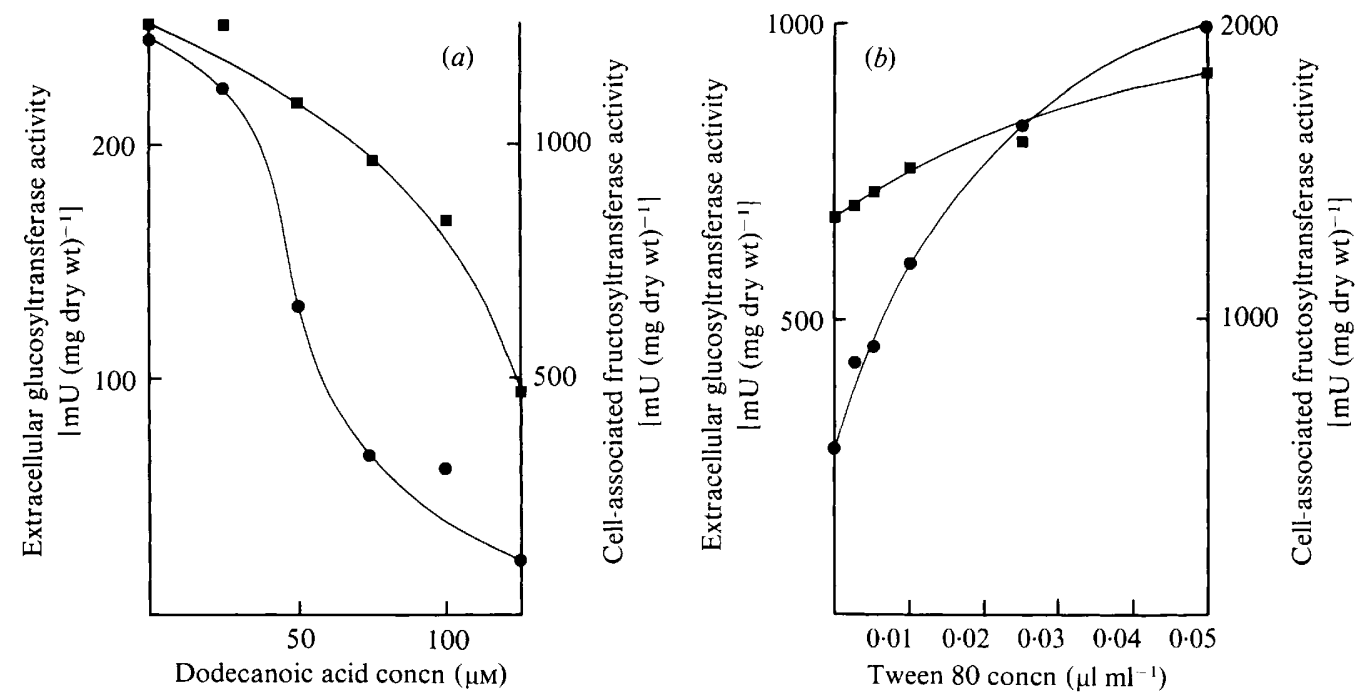

Fig. 1. Effect of (a) dodecanoic acid and (b) Tween 80 on the expression of cell-associated fructosyltransferase activity $(\boldsymbol{\square})$ and extracellular glucosyltransferase activity $(\boldsymbol{O})$ in non-proliferating cell suspensions.

Table 1. Effect of chloramphenicol on the production of cell-associated fructosyltransferase and extracellular glucosyltransferase in non-proliferating cell suspensions

Cells from a $100 \mathrm{ml}$ culture were harvested by centrifugation at mid-exponential phase and used to establish non-proliferating cell suspensions. Enzyme production was taken as the difference in the enzyme activities at zero time and after $120 \mathrm{~min}$ incubation at $37^{\circ} \mathrm{C}$.

$\begin{array}{cccc}\begin{array}{c}\text { Time } \\ (\mathrm{min})\end{array} & \begin{array}{c}\text { Chloramphenicol } \\ \left(\mu \mathrm{g} \mathrm{m}^{-1}\right)\end{array} & \begin{array}{c}\text { Fructosyltransferase activity } \\ {\left[\mathrm{mU}(\mathrm{mg} \mathrm{dry} \mathrm{wt})^{-1}\right]}\end{array} & \begin{array}{c}\text { Glucosyltransferase activity } \\ {\left[\mathrm{mU}(\mathrm{mg} \mathrm{dry} \mathrm{wt})^{-1}\right]}\end{array} \\ 0 & 0 & 553 & 0 \\ 120 & 0 & 1807 & 300 \\ \text { Difference } & 0 & 1254 & 300 \\ 0 & 50 & 553 & 0 \\ 120 & 50 & 632 & 25 \\ \text { Difference } & 50 & 79 & 25\end{array}$

medium without prior treatment of the cells in the standard inactivation system. This method also measured newly expressed enzyme activities (Table 1), but the absolute values of cellassociated fructosyltransferase and extracellular glucosyltransferase were reproducible to values of $1396 \pm 118 \mathrm{mU}(\mathrm{mg} \mathrm{dry} \mathrm{wt})^{-1}$ and $283 \pm 36 \mathrm{mU}(\mathrm{mg} \text { dry wt })^{-1}$, respectively (mean $\left.\pm \mathrm{SD}\right)$.

\section{Effect of dodecanoic acid, Tween 80 and octylglucoside on cell-associated fructosyltransferase and extracellular glucosyltransferase production in non-proliferating cell suspensions}

Dodecanoic acid prevented both the expression of cell-associated fructosyltransferase and the production of extracellular glucosyltransferase (Fig. la). However, a higher concentration about $110 \mu \mathrm{M}$ - of dodecanoic acid was required to elicit a $50 \%$ inhibition of the expression of cell-associated fructosyltransferase compared with the concentration of about $50 \mu \mathrm{M}$ required to produce an equivalent inhibition in extracellular glucosyltransferase production.

Differences in the degree of expression of the two enzymes also occurred in the presence of Tween 80 . The expression of extracellular glucosyltransferase was enhanced several-fold by $0.05 \mu \mathrm{l}$ Tween $80 \mathrm{ml}^{-1}$ while the expression of cell-associated fructosyltransferase was only stimulated by $35 \%$ in the presence of an equivalent concentration of Tween 80 (Fig. 1 b). 


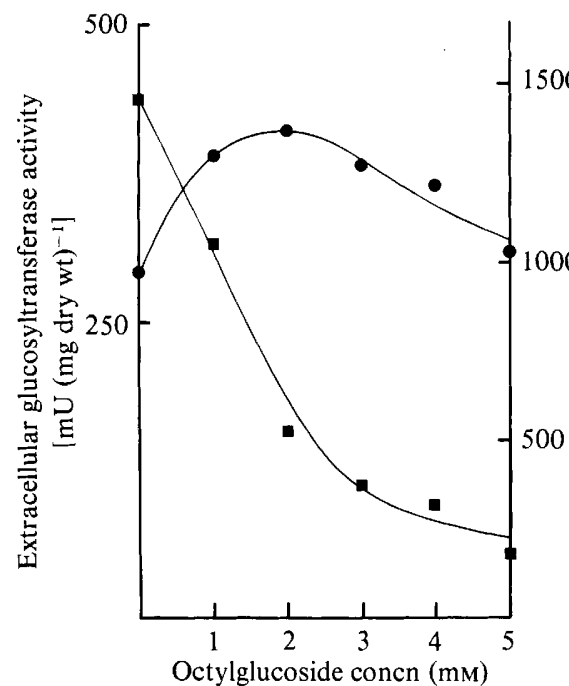

Fig. 2

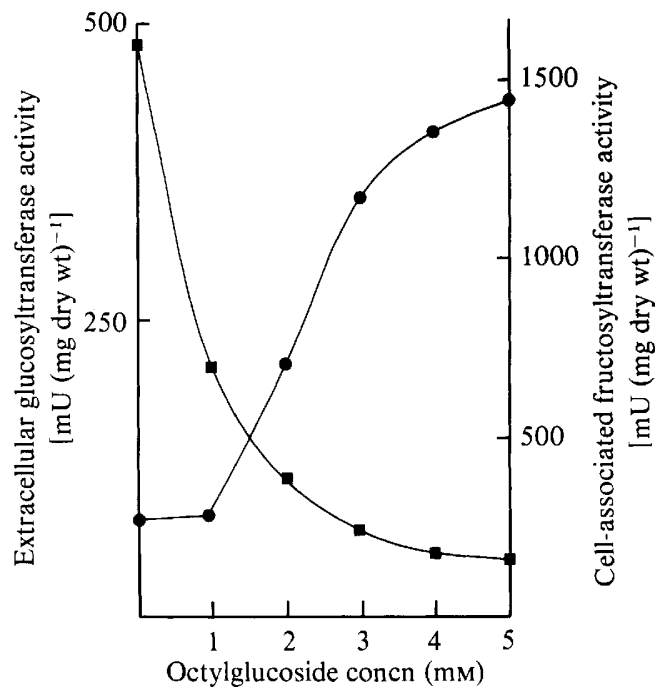

Fig. 3

Fig. 2. Inhibition of the expression of cell-associated fructosyltransferase activity by octylglucoside in non-proliferating cell suspensions. $\boldsymbol{\square}$, Cell-associated fructosyltransferase activity; $\mathbf{O}$, extracellular glucosyltransferase activity.

Fig. 3. Differential effect of octylglucoside on the expression of cell-associated fructosyltransferase activity ( $\square$ ) and extracellular glucosyltransferase activity (O) in batch culture.

Octylglucoside, however, had a differential effect on the expression of the two enzymes. Increasing concentrations of octylglucoside within the range $0-5 \mathrm{mM}$ prevented the expression of cell-associated fructosyltransferase activity. In contrast, extracellular glucosyltransferase production reached a maximum at 2 mM-octylglucoside, falling to a value similar to that observed in the absence of added detergent at a concentration of $5 \mathrm{~mm}$ (Fig. 2).

Octylglucoside in the range $0-5 \mathrm{~mm}$ had no effect on the activity of either enzyme when added to the assay mixture. Furthermore, the results presented in Fig. 2 implied that the cell-associated fructosyltransferase activity present in the harvested cells $\left[683 \pm 126 \mathrm{mU}\left(\mathrm{mg}\right.\right.$ dry wt) ${ }^{-1}$ (mean $\pm \mathrm{SD}$ )] was detected at the end of the $120 \mathrm{~min}$ incubation in the non-proliferating cell suspension medium even in the presence of $5 \mathrm{~mm}$-octylglucoside. As this activity was also recovered when $50 \mu \mathrm{g}$ chloramphenicol $\mathrm{ml}^{-1}$ was added to the suspension mixture (data not shown), the detergent appeared only to affect the expression of newly formed enzyme and not to alter the activity of that already synthesized.

\section{Effect of octylglucoside on the expression of glycosyltransferases in batch culture}

When batch cultures of $S$. salivarius were grown in the presence of $0-5$ mM-octylglucoside, the degree of expression of cell-associated fructosyltransferase activity decreased with increasing concentrations of the detergent in a similar manner to that in non-proliferating cell suspensions. In contrast, extracellular glucosyltransferase production was stimulated approximately fivefold in the presence of 3-5 mM-octylglucoside (Fig. 3). In the absence of added detergent, the doubling time for $S$. salivarius was $32 \pm 3$ min (mean \pm SD). No change in this value was observed in the presence of 1-3 mM-octylglucoside. Detectable increases in the doubling times of the cells to $40 \pm 1 \mathrm{~min}$ and $58 \pm 2 \mathrm{~min}$ were not observed until the concentration of octylglucoside was increased to $4 \mathrm{mM}$ and $5 \mathrm{mM}$, respectively. A concentration of $10 \mathrm{~mm}$ octylglucoside was bacteriostatic. Since the inhibition of the expression of cell-associated fructosyltransferase by $3 \mathrm{mM}$-octylglucoside reached $94 \%$ of the value observed at a concentration of $5 \mathrm{~mm}$, it appeared that the detergent preferentially affected enzyme expression before any noticeable effects on the doubling time of the cells. 
Table 2. Fatty acid profiles of cells grown in the presence of octylglucoside

The results are the means of duplicate experiments. An unidentified fatty acid with a retention time between $C_{16: 1}$ and $C_{18: 0}$ was present in trace amounts $(<1 \%)$ in each sample.

\begin{tabular}{|c|c|c|c|c|c|c|c|}
\hline \multirow[b]{2}{*}{$\begin{array}{l}\text { Octyl- } \\
\text { glucoside } \\
\text { concn } \\
(\mathrm{mM})\end{array}$} & \multicolumn{6}{|c|}{ Amount of fatty acid $(\%)$} & \multirow[b]{2}{*}{$\underset{\text { ratio* }}{\mathrm{U} / \mathrm{S}}$} \\
\hline & $\begin{array}{c}\text { Tetra- } \\
\text { decanoic } \\
\left(\mathrm{C}_{14: 0}\right)\end{array}$ & $\begin{array}{c}\text { Hexa- } \\
\text { decanoic } \\
\left(\mathrm{C}_{16: 0}\right)\end{array}$ & $\begin{array}{l}\text { Hexa- } \\
\text { decenoic } \\
\left(C_{16: 1}\right)\end{array}$ & $\begin{array}{c}\text { Octa- } \\
\text { decanoic } \\
\left(\mathrm{C}_{18: 0}\right)\end{array}$ & $\begin{array}{c}\text { Octa- } \\
\text { decenoic } \\
\left(C_{18: 1}\right)\end{array}$ & $\begin{array}{l}\text { Eicos- } \\
\text { enoic } \\
\left(C_{20: 1}\right)\end{array}$ & \\
\hline 0 & $4 \cdot 3$ & $38 \cdot 7$ & $10 \cdot 4$ & $5 \cdot 9$ & $32 \cdot 1$ & $8 \cdot 6$ & 1.04 \\
\hline 1 & $5 \cdot 5$ & $42 \cdot 8$ & $9 \cdot 1$ & $6 \cdot 6$ & $29 \cdot 1$ & $7 \cdot 0$ & 0.82 \\
\hline 2 & $6 \cdot 2$ & $42 \cdot 1$ & $8 \cdot 8$ & 7.9 & $26 \cdot 3$ & 8.7 & 0.78 \\
\hline 3 & $5 \cdot 2$ & $42 \cdot 1$ & $6 \cdot 9$ & $9 \cdot 5$ & $27 \cdot 5$ & $8 \cdot 9$ & 0.76 \\
\hline 4 & 5.7 & $41 \cdot 6$ & $7 \cdot 7$ & $12 \cdot 8$ & $22 \cdot 6$ & $9 \cdot 6$ & 0.66 \\
\hline 5 & $3 \cdot 3$ & $42 \cdot 6$ & $6 \cdot 1$ & $16 \cdot 4$ & $23 \cdot 8$ & 11.9 & 0.61 \\
\hline
\end{tabular}

No increase in fructosyltransferase activity was evident in the cell-free culture fluid (approximately $10 \%$ of the cell-associated value) when cells were grown in the presence of octylglucoside up to a concentration of $5 \mathrm{~mm}$. When cells were lysed with a protease-free preparation of the $\mathrm{N}$-acetylmuramidase $\mathrm{M}-1$, no further fructosyltransferase activity was observed in the digests. For instance, in the absence of added detergent, cells with a measured cell-associated fructosyltransferase activity of $532 \mathrm{mU}(\mathrm{mg} \text { dry wt })^{-1}$ possessed an activity equivalent to $533 \mathrm{mU}$ (mg dry wt $)^{-1}$ after lysis. The corresponding values for cells grown in the presence of $5 \mathrm{~mm}$-octylglucoside were $61 \mathrm{mU}\left(\mathrm{mg}\right.$ dry wt) ${ }^{-1}$ for whole cells and $57 \mathrm{mU}(\mathrm{mg}$ dry wt $)^{-1}$ for the lysate. These results indicated that it was unlikely that octylglucoside was preventing either the attachment of newly secreted and active fructosyltransferase to the cell surface, or preventing transport of active preformed enzyme across the cytoplasmic membrane. The enhancement of extracellular glucosyltransferase synthesis and secretion under these circumstances lent further support to this view (Fig. 3).

It is of interest, however, that the rate of lysis by enzyme M-1 determined over a 90 min period was about threefold greater for cells grown in the presence of $5 \mathrm{~mm}$-octylglucoside than for those grown in its absence (data not shown).

\section{Reversibility of the effect of octylglucoside on cell-associated fructosyltransferase expression}

A culture $(50 \mathrm{ml})$ was grown in the presence of $5 \mathrm{~mm}$-octylglucoside to mid-exponential phase, harvested by centrifugation $\left(10000 \mathrm{~g}, 4^{\circ} \mathrm{C}, 10 \mathrm{~min}\right)$ and washed with $10 \mathrm{ml} 10 \mathrm{~mm}$-potassium phosphate buffer, $\mathrm{pH} 6.5$, containing $10 \mathrm{mM}-\mathrm{MgSO}_{4}$. Cells equilibrated to $37^{\circ} \mathrm{C}$ in $3 \mathrm{ml}$ of the same buffer were used to inoculate fresh medium either free of added octylglucoside or containing $5 \mathrm{mM}$-octylglucoside. An inoculum of $1 \mathrm{ml}$ cell suspension per $10 \mathrm{ml}$ medium was used. At various times, samples of the cultures were removed aseptically and harvested and washed as above in the presence of $50 \mu \mathrm{g}$ chloramphenicol ml${ }^{-1}$. Cells inoculated into medium free of octylglucoside generally remained in lag phase for $60 \mathrm{~min}$. After this period exponential growth ensued, and the level of cell-associated fructosyltransferase activity increased from about $100 \mathrm{mU}(\mathrm{mg} \text { dry wt })^{-1}$ to about $600 \mathrm{mU}\left(\mathrm{mg} \mathrm{dry} \mathrm{wt}^{-1}\right.$ after a further $90 \mathrm{~min}$. This reappearance of fructosyltransferase activity was prevented by the addition of $50 \mu \mathrm{g}$ chloramphenicol $\mathrm{ml}^{-1}$ to the culture medium. A low level [about $50 \mathrm{mU}\left(\mathrm{mg} \mathrm{dry} \mathrm{wt}^{-1}\right.$ ] of cell-associated fructosyltransferase activity was maintained throughout the $150 \mathrm{~min}$ incubation period by those cells reinoculated into medium containing $5 \mathrm{~mm}$-octylglucoside.

\section{Fatty acid composition of the membrane lipids of $S$. salivarius grown in the presence and absence of octylglucoside}

Table 2 shows the results for the analyses of the fatty acid profiles of the membrane lipids of $S$. salivarius grown to early stationary phase in the presence of different concentrations of octylglucoside. The unsaturated to saturated fatty acid ratio fell as the concentration of 
octylglucoside increased. This was due to an increase in octadecanoic acid at the expense of octadecenoic and hexadecenoic acids, since the level of the other unsaturated fatty acid, eicosenoic acid, slowly increased with increasing concentrations of octylglucoside. The results indicated that the membrane fatty acid composition of $S$. salivarius changed in response to the presence of octylglucoside in the culture medium, and consequently that the detergent was capable of perturbing the structure of the cytoplasmic membrane.

\section{DISCUSSION}

The problem of defining whether the fructosyltransferase of $S$. salivarius is associated with the cytoplasmic membrane or the peptidoglycan matrix with its associated polymers has been exacerbated by the inability, so far, to produce stable protoplasts free of the cell wall sacculus. Partial removal of the cell wall with the $N$-acetylmuramidase $\mathrm{M}-1$, results in the release of approximately $75 \%$ of the fructosyltransferase activity from the cell (Jacques \& Wittenberger, 1981). However, this release of enzyme activity is also accompanied by the release of lipid components (unpublished observations) implying that some disruption of the cytoplasmic membrane is occurring during spheroplast formation.

The present study indicated subtle differences in the effects of Tween 80 and dodecanoic acid on the expression of cell-associated fructosyltransferase compared with their effects on the truly secreted protein, glucosyltransferase. Octylglucoside, however, affected the expression of cellassociated fructosyltransferase and extracellular glucosyltransferase in a differential manner. While the altered pattern for the fatty acids of the membrane lipids indicated that octylglucoside could perturb the cytoplasmic membrane, the detergent also affected other surface properties since a significant increase in the rate of lysis of cells by enzyme M-1 was observed when cells were grown in the presence of octylglucoside. This may have been due to alterations in the peptidoglycan structure of the cell walls and/or its associated polymers (Knox et al., 1979), or due to activation of autolytic activity by the detergent (Ved et al., 1984). It should be borne in mind, however, that some of the enzymes required for cell wall biosynthesis are located in the cytoplasmic membrane underlying the cell wall sacculus, and that lipid carriers are required for translocation of cell wall intermediates across the membrane (Shockman \& Barrett, 1983). Consequently, detergent interaction with the cytoplasmic membrane could account for an altered cell wall structure by interfering with these processes. These alternative possibilities make it difficult to determine the primary site of action of octylglucoside in preventing the surface expression of fructosyltransferase in $S$. salivarius.

Octylglucoside did not inhibit fructosyltransferase activity nor did it cause an increase in intracellular activity. It could be argued that the detergent physically prevented the expression of the enzyme on the outer surface of the membrane and thus led directly or indirectly to inhibition of further synthesis of the protein. This would imply that fructosyltransferase was a (trans)membrane protein with its active site on the outer surface of the membrane. The failure of a hybrid lipoprotein to insert into the outer membrane of $E$. coli has recently focused attention on the importance of the lipid domain in the assembly of such membrane proteins (Yu et al., 1984).

Since extracellular glucosyltransferase production occurred at normal or enhanced rates under conditions where cell-associated fructosyltransferase expression was prevented by octylglucoside, one could envisage alternative explanations for the mode of action of the detergent. For instance, octylglucoside could be affecting the activation of the enzyme either by preventing its modification on association with the membrane by interfering with a mechanism similar, say, to that for the cell-association of penicillinase (Chang et al., 1982; Neilsen \& Lampen, 1982), or by similarly interfering with its association with components of the cell wall sacculus. A third possible explanation is that another enzyme(s) is required for activation of fructosyltransferase and that the detergent interferes with the expression of the activity of this enzyme. The existence of multiple molecular weight species of fructosyltransferase in some oral streptococci (Jacques \& Wittenberger, 1981; Russell et al., 1983a) could be explained by any of these latter alternatives. It has also been suggested that modulation of the components $(\Delta \psi, \Lambda \mathrm{pH})$ of the proton motive force $\Delta \bar{\mu}_{\mathrm{H}^{+}} / \mathrm{F}$ can lead to alterations in the levels of extracellular glycosyltransferases in oral 
streptococci (Keevil et al., 1984; West et al., 1984). Thus a possible fourth explanation for the effects of octylglucoside is that the surfactant alters the $\Delta \bar{\mu}_{\mathrm{H}^{+}} / \mathrm{F}$ or its components so as to enhance extracellular glucosyltransferase production while suppressing cell-associated fructosyltransferase expression. However, direct correlations between modulation of $\Delta \bar{\mu}_{\mathrm{H}^{+}} / \mathrm{F}$ and changes in the expression of glycosyltransferases in oral streptococci have not yet been forthcoming as no direct measurements have been made of the components of the $\Delta \bar{\mu}_{\mathrm{H}^{+}} / \mathrm{F}$ under the conditions that produce changes in the levels of the enzymes (Markevics \& Jacques, 1985). Regardless of the mechanism prevailing, however, the fructosyltransferase of $S$. salivarius would not appear to be secreted in an active form across the cytoplasmic membrane in the same manner as glucosyltransferase to become subsequently associated with the cell surface.

This work was supported by a Post-Doctoral Fellowship awarded by the National Health and Medical Research Council of Australia.

\section{REFERENCES}

Alonso, A., Saez, R., Villena, A. \& Goni, F. M. (1982). Increase in size of sonicated phospholipid vesicles in the presence of detergents. Journal of Membrane Biology 67, 55-62.

Chang, C. N., Nielsen, J. B. K., Isui, K., Blobel, G. \& LAMPEN, J. O. (1982). Identification of the signal peptidase cleavage site in Bacillus licheniformis prepenicillinase. Journal of Biological Chemistry 257, 4340-4344.

GARSZCZYNSKI, S. M. \& EDWARDS, J. R. (1973). Synthesis of a broth levan by a cell-bound levansucrase from Streptococcus salivarius. Archives of Oral Biology 18, 239-251.

Helenius, A., McCaslin, D. R., Fries, E. \& TaNFORD, C. (1979). Properties of detergents. Methods in Enzymology 56, 734-750.

ICHiHARA, S., Hussain, M. \& Mizushima, S. (1982). Mechanism of export of outer membrane lipoproteins through the cytoplasmic membrane in Escherichia coli. Journal of Biological Chemistry 257, 495500 .

JACQUES, N. A. (1983). Membrane perturbation by cerulenin modulates glucosyltransferase secretion and acetate uptake by Streptococcus salivarius. Journal of General Microbiology 129, 3293-3302.

JACQUES, N. A. (1984). Calcium dependence of the cellassociated fructosyltransferase of Streptococcus salivarius. Carbohydrate Research 127, 349-355.

JACQUES, N. A. \& WITTENBERGER, C. L. (1981). Inactivation of cell-associated fructosyltransferase in Streptococcus salivarius. Journal of Bacteriology 148, $912-918$.

JaCQues, N. A., JacQues, V. L., Wolf, A. C. \& WitTENBERGER, C. L. (1985). Does an increase in membrane unsaturated fatty acids account for Tween 80 stimulation of glucosyltransferase secretion by Streptococcus salivarius? Journal of General Microbiology 131, 67-72.

Keevil, C. W., West, A. A., Bourne, N. \& Marsh, P. D. (1984). Inhibition of the synthesis and secretion of extracelluiar glucosyl- and fructosyltransferase in Streptococcus sanguis by sodium ions. Journal of General Microbiology 130, 77-82.

Knox, K. W., Jacques, N. A., Campbell, L. K., Wicken, A. J., Hurst, S. F. \& Bleiweis, A. S. (1979). Phenotypic stability of the cell wall of
Streptococcus mutans Ingbritt grown under various conditions. Infection and Immunity 26, 1071-1078.

Markevics, L. J. \& Jacques, N. A. (1985). Enhanced secretion of glucosyltransferase by changes in potassium ion concentrations is accompanied by an altered pattern of membrane fatty acids in Streptococcus salivarius. Journal of Bacteriology 161, 989994.

Neilsen, J. B. K. \& Lampen, J. O. (1982). Membranebound penicillinases in Gram-positive bacteria. Journal of Biological Chemistry 257, 4490-4495.

Petit-Glatron, M. F. \& Chambert, R. (1981). Levansucrase of Bacillus subtilis: conclusive evidence that its production and export are unrelated to fatty acid synthesis but modulated by membranemodifying agents. European Journal of Biochemistry 119, 603-611.

Russell, R. R. B., Donald, A. C. \& Douglas, C. W. I. $(1983 a)$. Fructosyltransferase activity of a glucanbinding protein from Streptococcus mutans. Journal of General Microbiology 129, 3243-3250.

Russell, R. R. B., Peach, S. L., Colman, G. \& CoHEN, B. (1983b). Antibody responses to antigens of Streptococcus mutans in monkeys (Macaca fascicularis) immunized against dental caries. Journal of General Microbiology 129, 865-875.

Shockman, G. D. \& Barrett, J. F. (1983). Structure, function, and assembly of cell walls of Grampositive bacteria. Annual Review of Microbiology 37, 50!-527.

Siegel, J. L., Hurst, S. F., Lieberman, E. S., Colman, S. E. \& BleIweIS, A. S. (1981). Mutanolysin-induced spheroplasts of Streptococcus mutans are true protoplasts. Infection and Immunity 31, 808-815.

UMESAKI, Y., KaWAI, Y. \& MUTAI, M. (1971). Effect of Tween 80 on glucosyltransferase production in Streptococcus mutans. Applied and Environmental Microbiology 34, 115-119.

Ved, H. S., Gustow, E., Mahadevan, V. \& PierINGER, R. A. (1984). Dodecylglycerol. A new type of antibacterial agent which stimulates autolysin activity in Streptococcus faecium ATCC 9790. Journal of Biological Chemistry 259, 8115-8121.

West, A. A., Keevil, C. W., Marsh, P. D. \& ELLwOOD, D. C. (1984). The effect of ionophores on growth and glycosyltransferase production of Strep- 
tococcus sanguis. FEMS Microbiology Letters 25, Yokogawa, K., Kawata, S., Takemura, T. \& $133-137$.

Yoshimura, Y. (1975). Purification and properties

Wittenberger, C. L., Beaman, A. J. \& Lee, L. N. of lytic enzymes from Streptomyces globisporus 1829. (1978). Tween 80 effect on glucosyltransferase synthesis of Streptococcus salivarius. Journal of Bacteriology 133, 231-239.

WOLFE, P. B. \& WiCKNER, W. (1984). Bacterial leader peptidase, a membrane protein without a leader peptide, uses the same export pathway as presecretory proteins. Cell 36, 1067-1072. Agricultural and Biological Chemistry 39, 15331543.

Yu, F., Furukawa, H., Nakamura, K. \& Mizushima, S. (1984). Mechanism of location of major outer membrane lipoprotein in Escherichia coli. Studies with the omp F-lipoprotein hybrid protein. Journal of Biological Chemistry 259, 6013-6018. 